\title{
Effect of Subsidized Fertilizer Policy, Channel Distribution of Subsidized Fertilizer Fertilizer Marketing And Performance Against Rice Farmers' Income in Padang
}

\author{
Fajri \\ Program Studi Magister Manajemen Sekolah Tinggi Ilmu Ekonomi KBP \\ fajrisp31@gmail.com
}

\begin{abstract}
The purpose of this study are: 1) To explain the presence or absence of policy influence of subsidized fertilizer, distribution channels fertilizer and income of farmers marketing of fertilizers to farmers' income and 2) Measure the level of influence the policy of subsidized fertilizer, distribution channels fertilizer and marketing performance fertilizers on the income of farmers, traders and fertilizer distributor. This research was conducted in February-March 2016 in the city of Padang. From the initial research and the description above, the authors conclude that the income of farmers is still low and less than optimal. The sample used in this study were 89 respondents using saturation sampling. The independent variables in this study is the policy of subsidized fertilizer, fertilizer distribution channels, and marketing performance fertilizer while the dependent variable is the income of farmers. This study is an explanation. Techniques of data collection is questionnaire. Technical analysis of the data using descriptive analysis and inferential analysis. To determine the effect of independent variables on the dependent variable partially, $t$ test was used. Meanwhile, to determine the effect of independent variables on the dependent variable simultaneously, used $F$ test assumptions used in the test of validity is if $R$-count $>R$-table item declared invalid. Based on test validity policy of subsidized fertilizer, fertilizer distribution channels, marketing performance and income of farmers fertilizers known to all items declared invalid meet the eligibility criteria are good and reliable instrument. The regression analysis of subsidized fertilizer policy values obtained $t=2.091$ while $t$ table $=1.988$, and the significance value is 0,040 this value is smaller than $\alpha=0.05$ not significant effect on the income of farmers, Fertilizer Distribution Channels regression analysis obtained by value $t=1,762$ while the value table $=1,988$ so thitung <t table and the significance value is 0.082 this value is greater than $\alpha=0.05$ significant effect on the incomes of farmers and Marketing performance regression analysis obtained by value $t=-0.685$ while the value t table $=1.988$ so $t<$ t table and the significance value is 0,495 , this value is greater than $\alpha=0.05$, significant impact on farmers' income.
\end{abstract}

Keywords: Policy Subsidized Fertilizer, Fertilizers Distribution Channels, Marketing and Revenue Performance farmers 


\section{PENDAHULUAN \\ Latar Belakang Penelitian}

Sektor pertanian merupakan sektor yang memiliki peranan yang signifikan dalam pembangunan perekonomian Indonesia. Selain sebagai sektor yang mampu menyediakan pangan bagi penduduk Indonesia, pertanian juga mampu menyerap 46,5 persen dari total angkatan kerja di Indonesia, dan mampu memberikan kontribusi sebesar 14,7 persen bagi GNP. Begitu besarnya peranan sektor pertanian, pemerintah berusaha untuk menunjang sektor pertanian tersebut, salah satunya melalui industri pupuk.

Keberadaan industri pupuk di dalam negeri memiliki peranan strategis dalam menunjang program pembangunan perekonomian Indonesia. Secara nasional keberadaan industri pupuk mampu memberikan andil yang cukup besar tidak saja bagi perkembangan sektor pertanian khususnya tanaman pangan, namun juga memberikan dampak bagi perkembangan di sektor perkebunan, industri kimia dan bidang jasa lain. Kebutuhan pupuk dalam negeri mengalami peningkatan sekitar 4,6 persen per tahun, seiring dengan masifnya program intensifikasi dan peningkatan produktivitas komoditas pangan yang dicanangkan pemerintah (Rachman, 2003). Permintaan pupuk yang terus meningkat menuntut peningkatan volume produksi pupuk dan penyesuaian kebijakan perdagangan pupuk dalam upaya menjaga kontinuitas pasokan pupuk dalam negeri.

Dalam konteks pembangunan pertanian, pupuk merupakan salah satu unsur penting dan strategis dalam peningkatan produksi dan produktivitas serta menjadi bagian yang tidak terpisahkan dari sistem usahatani. Menurut Hadi (2007), pupuk merupakan salah satu input sangat esensial dalam proses produksi pertanian. Disebut demikian karena tanpa pupuk, penggunaan input lainnya seperti benih unggul, air dan tenaga kerja hanya akan memberikan manfaat marjinal sehingga produktivitas pertanian dan pendapatan petani akan rendah.

Demikian penting dan strategisnya peranan pupuk dalam meningkatkan produksi dan produktivitas tanaman sehingga pemerintah terus mendorong penggunaan pupuk dengan mengeluarkan beberapa kebijakan di antaranya adalah subsidi pupuk. Kebijakan pemberian subsidi pupuk telah berlangsung selama bertahun-tahun dan setiap tahun anggaran yang disediakan cenderung semakin lama semakin meningkat. Akan tetapi, dalam pelaksanaannya masih ditemukan beberapa permasalahan di antaranya adalah: kelangkaan pupuk di beberapa daerah sentra pertanian, penyelundupan pupuk ke luar negeri, lonjakan harga di atas HET, perembesan pupuk bersubsidi ke pasar non-subsidi dan antarwilayah (Kariyasa dan Yusdja, 2005).

Dikaitkan dengan fenomena yang terjadi saat ini dimana terjadinya kelangkaan pasokan dan lonjakan harga, maka dapat dikatakan bahwa program kebijakan pupuk yang amat komprehensif dibangun pemerintah tidak berjalan sebagaimana mestinya. Kebijakan komprehensif mengenai pupuk bersubsidi tersebut antara lain : (1) pembangunan industri pupuk untuk pemenuhan kebutuhan domestic dan sisanya untuk ekspor; (2) rayonisasi pasar; (3) pemberlakuan HET sesuai rayon sehingga tidak memberatkan/ menyulitkan petani untuk memperolehnya; (4) pabrik pupuk memperoleh subsidi gas sebagai imbalan pelaksanaan produksi dan distribusi pupuk bersubsidi sampai kios pengecer sesuai 
HET; (5) besaran subsidi pupuk sama dengan besaran subsidi gas dan volume pupuk bersubsidi yang disalurkan; (6) Pelaksanaan subsidi pupuk dan distribusinya diawasi oleh pemerintah dan DPR (Simatupang, 2004 dalam Kariyasa dan Yusdja, 2005).

Adapun penyebab terjadinya ketimpangan pelaksanaan kebijakan pupuk yang komprehensif tersebut karena dugaan adanya peningkatan ekspor pupuk ilegal baik melalui produsen pupuk itu sendiri maupun melalui penyelundup seiring peningkatan margin antara harga pupuk urea di pasar dunia dengan harga pupuk di pasar domestik, telah membuktikan bahwa produsen pupuk sudah tidak mengutamakan pemenuhan untuk pasar domestik, dan yang lebih memprihatinkan lagi bahwa pupuk urea yang diekspor secara ilegal tersebut adalah pupuk bersubsidi yang merupakan hak petani yang notabene merupakan kelompok masyarakat miskin.

Berdasarkan pada hal yang dikemukakan diatas tadi, maka penulis tertarik untuk meneliti lebih lanjut dalam bentuk suatu tesis yang berjudul " Dampak Kebijakan Pupuk bersubsidi, Saluran Distribusi dan Kinerja Pemasaran Pupuk Bersubsidi terhadap Pendapatan Petani Padi di Kota Padang".

\section{Perumusan Masalah}

1. Bagaimana pengaruh Kebijakan Pupuk bersubsidi terhadap Pendapatan Petani Padi di Kota Padang?

2. Bagaimana pengaruh Saluran Distribusi Pupuk Bersubsidi terhadap Pendapatan Petani Padi di Kota Padang?

3. Bagaimana pengaruh Kinerja Pemasaran Pupuk Bersubsidi terhadap Pendapatan Petani Padi di Kota Padang?

\section{Tujuan dan Manfaat Penelitian}

1.Untuk mengetahui pengaruh Pelaksanaan Kebijakan Pupuk bersubsidi terhadap Pendapatan Petani Padi di Kota Padang

2.Untuk mengetahui pengaruh Regulasi Pupuk Bersubsidi terhadap Pendapatan Petani Padi di Kota Padang?

3.Untuk mengetahui pengaruh Kinerja Pemasaran Pupuk Bersubsidi terhadap Pendapatan Petani Padi di Kota Padang?

Manfaat Teoritis

1. Menguji secara empiris hubungan variabel Kebijakan Pupuk bersubsidi, Regulasi Pupuk Bersubsidi dan Kinerja Pemasaran Pupuk Bersubsidi dalam Meningkatkan Pendapatan Petani Padi di Kota Padang.

2. Sebagai bahan pertimbangan bagi peneliti berikutnya terhadap temuan penelitian Dampak Kebijakan Pupuk bersubsidi, Regulasi Pupuk Bersubsidi dan Kinerja Pemasaran Pupuk Bersubsidi dalam Meningkatkan Pendapatan Petani Padi di Kota Padang.

Manfaat Praktis

1. Sebagai bahan masukan bagi pengambil kebijakan pada Dinas Pertanian Provinsi Sumatera Barat dalam Kebijakan Pupuk bersubsidi, Regulasi Pupuk Bersubsidi dan Kinerja Pemasaran Pupuk Bersubsidi dalam Meningkatkan Pendapatan Petani Padi. 
2. Sebagai bahan pertimbangan dalam pengambilan keputusan tentang mengalokasikan sumber daya dalam usaha meningkatkan Kebijakan Pupuk bersubsidi, Regulasi Pupuk Bersubsidi dan Kinerja Pemasaran Pupuk Bersubsidi di Provinsi Sumatera Barat

\section{TINJAUAN PUSTAKA DAN HIPOTESIS Pendapatan Petani}

Menurut Prawirokusumo (1990) ada beberapa pembagian pendapatan yaitu (1) Pendapatan kotor (Gross income) adalah pendapatan usahatani yang Belum dikurangi biaya-biaya, (2) Pendapatan bersih (net income) adalah pendapatan setelah dikurangi biaya, (3) Pendapatan pengelola (management income) adalah pendapatan merupakan hasil pengurangan dari total output dengan total input.

Input-input produksi atau biaya-biaya produksi adalah biaya yang dikeluarkan dalam proses produksi serta menjadi barang tertentu atau menjadi produk akhir, dan termasuk didalamnya dan termasuk didalamnya adalah barang yang dibeli dan jasa yang dibayar. Ada beberapa konsep biaya dalm ekonomi yaitu 1) Biaya tetap (FC), 2) Biaya total tetap (TFC), 3) Biaya Variabel (VC) dan 4) Biaya total variabel (TVC) serta Biaya tunai dan tidak tunai.

Pendapatan usaha tani adalah besarnya manfaat atau hasil yang diterima oleh petani yang dihitung berdasarkan dari nilai produksi dikurangi semua jenis pengeluaran yang digunakan untuk produksi. Untuk itu pendapatan usaha tani sangat dipengaruhi oleh besarnya biaya sarana produksi, biaya pemeliharaan, biaya pasca panen, pengolahan dan distribusi serta nilai produksi.

Pemberdayaan masyarakat adalah suatu proses perbaikan yang bertujuan untuk memberikan kemampuan pada siapapun agar mampu melakukan sesuatu yang bermanfaat. Proses perbaikan tersebut tidak dapat tercapai tujuan dan sasaran apabila tidak didukung oleh seluruh stakeholder yang tidak berupaya untuk memperbaiki diri memahami fakta, memahami kebutuhan, memahami permasalahan serta melakukan aksi untuk keberman-faatan semua. Untuk dapat meningkatkan efektifitas proses pemberdayaan masyarakat maka dilakukan pendampingan.

\section{Kebijakan Pupuk Bersubsidi}

Sasaran pupuk besubsidi adalah petani, pekebun, dan peternak yang mengusahakan lahan paling luas 2 hektar setiap musim tanam per keluarga petani kecuali pembudidaya ikan atau udang paling luas 1 hektar. Pupuk bersubsidi tidak diperuntukan bagi perusahaan tanaman pangan, holtikultura, perkebunan, perternakan, atau perusahaan perikanan budidaya.

Secara filosofis, subsidi pupuk dilakukan untuk membantu meringankan beban petani dalam membiayai usaha taninya. Selain persoalan biaya, petani juga menghadapi persoalan kemampuan dalam mengadopsi teknologi pemupukan untuk peningkatan produktifitas. Sehingga diperlukan terobosan program untuk mengatasi hal ini sebagai upaya peningkatan komoditas pertanian untuk ketahanan pangan yang berkelanjutan. Upaya yang selama ini dilakukan pemerintah untuk mendukung peningkatan produktifitas hasil pertanian melalui teknologi 
pemupukan adalah program pupuk bersubsidi. Konsep dasar pemberian subsidi untuk petani telah digagas sejak tahun 1970-an.

Berdasarkan sistem subsidi dan sumber pembiayaan, sejarah kebijakan subsidi pupuk Periode 2006 - sekarang, sistem subsidi pada periode ini merupakan pembaharuan dari sistem subsidi pada periode 2003-2005. Seperti pada periode sebelumnya sistem subsidi di periode ini menggunakan sistem subsidi harga dengan formula selisih antara HET dengan HPP dan biaya distribusi dikalikan volume produksi, akan tetapi yang membedakan yaitu pada periode ini semua pupuk baik urea maupun non urea menggunakan sistem subsidi harga yang sama.

\section{Saluran distribusi pupuk bersubsidi}

Kebutuhan pupuk dihitung melalui beberapa tahapan, yaitu berdasarkan usulan kebutuhan teknis di lapangan yang diajukan oleh pemerintah daerah secara berjenjang dari Bupati/Walikota kepada Gubernur dan selanjutnya disampaikan kepada Menteri Pertanian dan didasari pada Program Peningkatan Produksi Pertanian. Usulan kebutuhan pupuk bersubsidi secara buttom up tersebut diproses di tingkat pusat dengan memperhatikan kemampuan daya serap pupuk di masingmasing wilayah selama beberapa tahun terakhir serta anggaran subsidi pupuk yang ditetapkan pemerintah.

Penetapan alokasi pupuk bersubsidi untuk masing-masing provinsi pada umumnya di bawah kebutuhan teknis yang diusulkan daerah karena terbatasnya anggaran subsidi, sehingga dengan jumlah pupuk bersubsidi yang terbatas tersebut, diharapkan agar tetap dapat dimanfaatkan secara optimal dengan memperhatikan azas prioritas, baik terhadap daerah yang dinilai sebagai sentra produksi, maupun terhadap jenis komoditas yang akan diunggulkan oleh daerah. Di samping itu, diharapkan dapat dilaksanakannya efisiensi penggunaan pupuk bersubsidi melalui penerapan pemupukan berimbang spesifik lokasi dan standar teknis yang dianjurkan disertai dengan penggunaan pupuk organik.

Alokasi pupuk bersubsidi tersebut dirinci menurut Subsektor, Kecamatan, jenis dan jumlah. Selain itu alokasi pupuk bersubsidi harus memperhatikan usulan yang diajukan oleh petani, pekebun, peternak, pembudidaya ikan atau udang berdasarkan Rencana Definitif Kebutuhan Kelompok (RDKK) yang disetujui oleh penyuluh pertanian dan kepala desa setempat.

Saluran distribusi untuk suatu barang adalah saluran yang digunakan oleh produsen untuk menyalurkan barang tersebut dari produsen sampai ke konsumen atau pemakai industri. Dari definisi tersebut tampak adanya lembaga-lembaga yang ikut ambil bagian dalam penyaluran barang yaitu produsen, perantara (pedagang dan agen) dan konsumen akhir atau pemakai industri.

Stern dan El-ausary mendefinisikan saluran pemasaran sebagai suatu perangkat organisasi-organisasi yang saling tergantung, yang terlibat dalam proses pembuatan produk atau jasa yang tersedia untuk digunakan atau dikonsumsi.

Bagi perusahaan atau produsen yang tidak memiliki sumber daya keuangan untuk mengadakan pemasaran langsung, maka akan menunjuk beberapa perantara di masing-masing wilayah pemasarannya. Hal ini dilakukan karena kesulitan- 
kesulitan yang dihadapi perusahaan apabila menangani sendiri seluruh wilayah pemasarannya yang mungkin menjangkau ke pasar internasional.

PT Pupuk Sriwidjaja dipercaya oleh pemerintah untuk monopoli dalam bidang penyaluran pupuk di Indonesia. PT. Pusri itu sendiri juga sebagai produsen pupuk urea yang mempunyai lokasi pabrik di Palembang Sumatera Selatan. Dalam penyaluran atau distribusi pupuk urea tersebut PT. Pupuk Sriwidjaja mendirikan kantor pemasaran wilayah yang terletak di ibukota propinsi.

\section{Kinerja Pemasaran}

Ferdinand (1999) mengemukakan kinerja pemasaran merupakan faktor yang umum digunakan untuk mengukur dampak dari sebuah strategi perusahaan. Strategi perusahaan selalu diarahkan untuk menghasilkan kinerja pemasaran seperti volume penjualan, porsi pasar dan tingkat pertumbuhan penjualan maupun kinerja keuangan. Disarankan pengukuran kinerja menggunakan aktivitasaktivitas pemasaran yang menghasilkan kinerja yaitu unit yang terjual dan perputaran pelanggan (Ferdinand, 2000). Pertumbuhan penjualan merupakan konsep untuk mengukur prestasi pasar suatu produk. Pertumbuhan penjualan merupakan sumber pertumbuhan pangsa pasar. Pertumbuhan penjualan digunakan untuk semua peneliti sebagai salah satu variabel pembentuk kinerja pasar. Kinerja pasar merupakan bagian dari kinerja pemasaran (Mckee, et al, 1989 dalam Han, et al, 1998, p.36 dan permadi, 1998, p.75).

\section{Hubungan Kebijakan pupuk bersubsidi dengan Kinerja Pemasaran}

Kinerja pemasaran merupakan konsep untuk mengukur prestasi perusahaan dalam pasar terhadap suatu produk. Setiap perusahaan berkepentingan untuk mengetahui prestasinya sebagai cermin dari keberhasilan usahanya dalam persaingan pasar. Morgan dan Piercy (1998, p.196) menyatakan bahwa strategi yang berkualitas dapat menimbulkan daya terima pelanggan terhadap tingkatan kualitas, perbaikan pasar dan kinerja. Kinerja pemasaran diidentifikasikan sebagai usaha pengukuran tingkat kinerja strategi yang diimplementasikan dengan volume penjualan, pertumbuhan penjualan dan tingkat keuntungan perusahaan (Menon Bharadwaj dan Howell, 1996 dalam Menon et al, 1999). Menurut Richard P. Bagozi (1980, p.7) atribut kinerja pemasaran yang dapat diukur antara lain melalui volume penjualan dan pertumbuhan penjualan.

Ferdinand (1999) mengemukakan kinerja pemasaran merupakan faktor yang umum digunakan untuk mengukur dampak dari sebuah strategi perusahaan. Strategi perusahaan selalu diarahkan untuk menghasilkan kinerja pemasaran seperti: volume penjualan, porsi pasar dan tingkat pertumbuhan penjualan maupun kinerja keuangan. Disarankan pengukuran kinerja menggunakan aktivitasaktivitas pemasaran yang menghasilkan kinerja yaitu unit yang terjual dan perputaran pelanggan (Ferdinand, 2000). Pada penelitan yang lain kinerja dapat diukur dari dimensi market share (Permadi, 1998).

\section{Hubungan Kinerja Pemasaran dengan Kepuasan Pelanggan}

Terdapat beberapa kriteria dalam menilai suatu kinerja yang disampaikan dalam berbagai literatur. Kriteria tersebut meliputi finansial maupun non finansial. Kriteria-kriteria yang berbeda dalam mengukur kinerja tersebut sebenarnya bergantung pada pengukuran kinerja itu sendiri. Tolak ukur bersifat unik, karena adanya kekhususan pada setiap badan usaha, antara lain bidang 
usaha, latar belakang, status hukum, struktur permodalan, tingkat pertumbuhan dan tingkat teknologi yang digunakan oleh perusahaan (Soeharto (1996) dalam Hatmoko, 2000). Kinerja perusahaan dapat dilihat dari profitability, pencapaian utama perusahaan, pertumbuhan, inovasi, tingkat pengembalian asset (Denison, Daniel R dan Misra, Aneil K, 1995, 213). Kemampuan dimaksudkan untuk mengetahui kemampuan dalam menghasilkan laba dan untuk mengetahui seberapa jauh perusahaan dikelola secara efektif. (Dawes, 2000) menyatakan bahwa persepsi manajer atas kemampulabaan perusahaan dapat menjadi pengukur kinerja yang baik.

Harisis dan Ogbonna (2001) dan Bae Lawler (2001), menyatakan bahwa kinerja merupakan ukuran keberhasilan atau prestasi yang telah dicapai oleh suatu organisasi maupun individu yang diukur tiap kurun waktu tertentu. Kinerja adalah pencapaian usaha sebagaimana tujuan perusahaan tersebut didirikan yaitu mendapatkan keuntungan sebesar-besarnya untuk dapat menopang pertumbuhan dan perkembangan.

\section{Penelitian Terdahulu}

\section{Pengaruh kebijakan pupuk bersubsidi terhadap kepuasan pelanggan}

Joko Sugihartono NIM. C4A-006302, Analisis pengaruh citra, kualitas layanan dan kepuasan terhadap loyalitas pelanggan, Kepuasan pelanggan akan tercapai apabila harapan sesuai dengan kenyataan yang diterima. Zeithaml, Valarie \& Mario Jo Bitner (1996) menyatakan bahwa kepuasan pelanggan tinggi apabila nilai yang dirasakan melebihi harapan pelanggan. Penerimaan produk dengan kualitas yang lebih tinggi akan mendapatkan tingkat kepuasan yang lebih tinggi daripada penerimaan produk dengan kualitas yang lebih rendah (Kennedy et. al.,2001). Pelanggan PT. Pupuk Kalimantan Timur SR Grobogan rata-rata puas dengan produk perusahaan, karena memiliki mutu dan kualitas yang baik. Dalam persaingan yang semakin ketat, usaha untuk memberikan kualitas pelayanan yang tinggi dan menciptakan kepuasan pelanggan yang tinggi dirasakan sangat penting bagi para pengusaha, karena menurut Cronin dan Taylor (1992); Teas (1993), kualitas pelayanan yang tinggi serta kepuasan pelanggan yang tinggi pada akhirnya akan menciptakan loyalitas pelanggan. Hasil penelitian ini membuktikan bahwa kualitas layanan berpengaruh pada loyalitas pelanggan PT. Pupuk Kalimantan Timur SR Grobogan. Kepuasan dan loyalitas pelanggan juga dipengaruhi oleh citra (Yi, 1992). Dan hasil penelitian lain yang dilakukan oleh Fred Selnes (1993), menyatakan bahwa citra merek mempunyai pengaruh positif terhadap loyalitas dan citra merek merupakan pemicu dari loyalitas. Hasil penelitian membuktikan bahwa reputasi berpengaruh positif terhadap loyalitas pelanggan PT. Pupuk Kalimantan Timur SR Grobogan.

Secara bersama, faktor motivasi, partisipasi, komunikasi memiliki pengaruh terhadap kinerja karyawan secara positif dan signifikan sebesar $93.80 \%$ ditemukan oleh Muhammad Rachmadi (2007) pada penelitiannya di PT. Bank Riau. Menurutnya hal ini disebabkan oleh motivasi yang tinggi akan meningkatkan semangat dan gairah kerja dan pada akhirnya akan meningkatkan kinerja karyawan. 


\section{Pengaruh kinerja pemasaran terhadap kepuasan pelanggan}

Menurut Robbins $(2001 ; 218)$ bahwa kinerja karyawan adalah fungsi integrasi kemampuan dan motivasi, hal ini dikarenakan dengan motivasi kerja yang tinggi, baik, kondusif, akan mendorong peningkatan kinerja karyawan yang ditandai dengan adanya semangat dan gairah kerja yang tinggi, peningkatan loyalitas, disiplin kerja yang tinggi, dan situasi kerja yang menyenangkan.

Pada penelitian lain yang dilakukan oleh Rasmianto (2005) mengenai hubungan antara kinerja pegawai dengan disiplin, ditemukannya bahwa hipotesis yang diajukannya dalam penelitian tersebut yaitu disiplin kerja berpengaruh terhadap kinerja pegawai pada Sekretariat Daerah Kabupaten Kerinci, dapat diterima dengan probabilitas koefisien $\mathrm{t}$ untuk disiplin kerja sebesar 0,021, sedangkan taraf signifikansi yang ditentukan adalah 0,05. Dari angka tersebut dalam penelitiannya ia berkesimpulan bahwa semakin tinggi disiplin kerja pegawai maka kinerja pegawai cenderung baik, dan hal yang sebaliknya juga berlaku.

Penelitian mengenai kaitan kinerja pegawai dan dukungan organisasi dilakukan oleh Nugraheny (2009). Dengan menggunakan motivasi sebagai faktor moderasi terhadap kinerja pegawai maka ia menemukan bahwa dukungan organisasional berpengaruh positif terhadap motivasi yang selanjutnya meningkatkan kinerja pegawai. Data empiris hasil penelitian ini menunjukkan pengaruh dukungan organisasional terhadap motivasi kerja menunjukkan nilai CR sebesar 2.164 dengan probabilitas sebesar 0.030. Oleh karena nilai probabilitas < 0.05 maka dapat disimpulkan bahwa dukungan organisasional berpengaruh positif dan signifikan terhadap motivasi kerja.

Pengaruh lingkungan persaingan terhadap kepuasan pelanggan

Penelitian yang dilakukan oleh Inda Ade Lisdasari (2007), yang berjudul "Pengaruh Relationship Marketing Terhadap Loyalitas Nasabah pada PT Bank Jatim Cabang Malang". Penelitian ini bertujuan untuk mengetahui dan menganalisis pengaruh relationship marketing yang terdiri atas keuntungan bersama (mutual benefit), komitmen, komunikasi, dan kebenaran (authencity) terhadap loyalitas nasabah Bank Jatim. Cabang Malang, baik secara simultan mupun parsial, serta untuk mengetahui variabel mana yang paling dominan. Jenis penelitian ini adalah penelitian eksplanatoris. Sampel yang diambil adalah sebesar 140 orang nasabah PT Bank Jatim Cabang Malang melalui kuisioner, wawancara, dan dokumentasi. Metode penelitian yang digunakan adalah regresi linier berganda. Variabel dependent (terikat) yaitu loyalitas nasabah dan variabel independent (bebas) yaitu relationship marketing yang terdiri dari variabel: keuntungan bersama (mutual benefit) $\left(\mathrm{X}_{1}\right)$, komitmen $\left(\mathrm{X}_{2}\right)$, komunikasi $\left(\mathrm{X}_{3}\right)$, dan kebenaran (authencity) ( $\mathrm{X}_{4}$ ). Hasil analisis yang diperoleh yaitu bahwa dari keempat variabel bebas tersebut mempunyai pengaruh positif dan signifikan terhadap variabel terikat, keuntungan bersama (mutual benefit) dengan $\beta_{1}=0.432$, komitmen dengan $\beta_{2}=0.213$, komunikasi dengan $\beta_{3}=0.265$, dan kebenaran (authencity) dengan $\beta_{4}=0.271$. Secara simultan semua variabel bebas mempunyai pengaruh yang signifikan terhadap struktur keuangan dengan signifikasi sebesar $0.000(0.000<0.05)$, dengan koefisien determinasi (adjusted $\mathrm{R}^{2}$ ) 0.551 atau $55.1 \%$. Variabel yang berpengaruh dominan terhadap loyalitas 
nasabah adalah komitmen dengan koefisien beta terstandarisasi sebesar 0.305. 2 . Penelitian yang dilakukan oleh Niken Amalia Habiba, yang berjudul "Pengaruh Relationship Marketing Terhadap Loyalitas Nasabah Bank Rakyat Indonesia (Persero) Tbk. Cabang Malang Kawi dengan Gender sebagai Variabel Moderator". Penelitian ini bertujuan untuk mengetahui pengaruh secara simultan dan parsial relationship marketing (komuniksi, komitmen, trust, dan kepuasan kinerja) dengan gender sebagai variabel moderator terhadap loyalitas nasabah Bank Rakyat Indonesia (Persero) Tbk. Cabang Malang Kawi. Sampel yang diambil adalah sebesar 180 responden. Metode penelitian yang digunakan adalah penelitian explanatory. Sedangkan untuk mengetahui pengaruh relationship marketing (komuniksi, komitmen, trust, dan kepuasan kinerja) dengan gender sebagai variabel moderator terhadap loyalitas nasabah digunakan uji $\mathrm{F}$ dan uji $\mathrm{t}$ dalam analisis regresi linier berganda dengan menggunakan slope atau moderator effect. Berdasarkan hasil analisis regresi berganda dengan menggunakan slope atau moderator effect, diketahui bahwa relationship marketing yang terdiri dari komuniksi, komitmen, trust, dan kepuasan kinerja berpengaruh terhadap loyalitas nasabah dengan gender sebagai variabel moderator secara simultan, namun tidak secara parsial. Hal ini menunjukkan bahwa relationship marketing dengan gender sebagai variabel moderator memiliki kontribusi terhadap loyalitas nasabah.

\section{METODE PENELITIAN}

\section{Populasi dan Sampel}

Menurut Nawawi ( 1991) Populasi adalah keseluruhan objek penelitian yang dapat terdiri dari manusia, benda - benda, hewan, tumbuhan, gejala - gejala, nilai tes atau peristiwa sebagai sumber data yang memiliki karakteristik tertentu dalam penelitian. Dalam penelitian ini populasi mencakup semua responden/individu yang dapat memberikan informasi yang merupakan sekelompok objek yang mampu memenuhi kebutuhan penelitian. Adapun populasi dari penelitian ini adalah petani padi/ konsumen pupuk, sebanyak 85 orang pelanggan.

Sampel adalah bagian dari jumlah dan karakteristik yang dimiliki oleh populasi (Sugiyono, 1999, p.73). Sampel dalam penelitian ini adalah pelanggan atau petani tanaman hias yang membeli dan memasarkan kepada konsumen akhir maupun yang melalui pedagang perantara. Pengambilan sampel dilakukan dengan cara stratified proportional random sampling berdasarkan tingkat jabatan struktural. Hal ini akan menghasilkan sampel sesuai dengan proporsi dari setiap kelompok strata populasi. Dalam penelitian ini digunakan metode sensus dimana jumlah sampel sama dengan jumlah populasi.

\section{Metode Pengumpulan Data Wawancara}

Nazir (1988) mendefinisikan bahwa wawancara adalah proses memperoleh data atau keterangan untuk tujuan penelitian dengan cara tanya jawab sambil bertatap muka antara pewawancara dengan penjawab atau responden dengan menggunakan alat yang dinamakan interview guide. 


\section{Kuesioner}

Kuesioner merupakan serangkaian pertanyaan yang dikirim per pos atau diserahkan pada responden untuk diisi, jawaban dari pertanyaan tersebut dilakukan sendiri oleh responden tanpa bantuan pihak peneliti, lalu jawaban kemudian dikembalikan oleh responden atas kemauannya sendiri (Anton,1995).

\section{Study pustaka}

Studi kepustakaan dilakukan untuk menghimpun informasi yang relevan dengan kebijakan pupuk bersubsidi, regulasi pupuk bersubsidi, kinerja pemasaran pupuk bersubsidi dan pendapatan petani padi kota Padang yang akan atau sedang diteliti. Informasi itu dapat diperoleh dari buku-buku ilmiah, laporan penelitian, karangan-karangan ilmiah, tesis dan disertasi, peraturan-peraturan, ketetapanketetapan, buku tahunan, ensiklopedia, dan sumber-sumber tertulis baik tercetak maupun elektronik lain.

\section{Metode Analisis Data}

Agar data yang dikumpulkan tersebut dapat bermanfaat, maka harus diolah dan dianalisis terlebih dahulu sehingga dapat dijadikan sebagai dasar dalam pengambilan keputusan. Adapun analisis yang digunakan sebagai berikut :

\section{Analisis Kualitatif}

Analisis data kualitatif adalah analisis yang berdasarkan data yang dinyatakan dalam bentuk uraian. Data kuantitatif merupakan data berupa informasi, uraian dalam bentuk bahasa prosa kemudian dikaitkan dengan data lainnya untuk mendapatkan kejelasan terhadap suatu kebenaran sehingga memperoleh gambaran baru atau menguatkan suatu gambaran yang sudah ada (Joko Subagyo,1997:106).

\section{Analisis Kuantitatif}

Analisis kuantitatif ini dimaksudkan untuk memperkirakan besarnya pengaruh secara kuantitatif dari perubahan satu atau beberapa kejadian lainnya dengan menggunakan statistik. Analisis statistik yang digunakan dalam penelitian ini adalah analisis regresi linear berganda kemudian analisis regresi sederhana.

Menurut Hermawan (1992) pengolahan data dengan analisis kuantitatif melalui tahapan-tahapan sebagai berikut:

1. Editing, yaitu kegiatan untuk memeriksa seluruh daftar pertanyaan yang dikembalikan oleh responden. Beberapa hal yang perlu diperhatikan dalam tahap ini adalah :

a. Kesesuaian jawaban dengan pertanyaan yang diajukan.

b. Kelengkapan pengisian daftar jawaban.

c. Konsistensi jawaban responden

2. Coding, yaitu kegiatan memberi tanda berupa angka pada jawaban responden yang diterima.

Tujuannya adalah untuk menyederhanakan jawaban.

a. Tabulasi, yaitu kegiatan menyusun dan menghitung data hasil pengkodean.

b. Skala pengukuran, yaitu sebuah tolak ukur tambahan yang memberikan suatu skor berdasarkan jumlah dan intensitas responden dalam serangkaian pertanyaan. Skala pengukuran yang digunakan pada penelitian ini adalah Agree-Disagree Scale. Pengukuran ini membagi responden ke dalam urutan rangking atas dasar sikapnya terhadap tindakan tertentu. Tingkatan skala 
ini disediakan alternatif jawaban dalam rentang 1 sampai dengan 10.

c. Menganalisa data, dalam menganalisis data digunakan analisis regresi linear berganda dan

d. analisis regresi linear sederhana dengan sebelumnya melakukan uji validitas dan reliabilitas untuk menguji item-item pertanyaan yang dipakai serta uji asumsi klasik untuk menguji kelayakan model regresi yang digunakan:

\section{Uji Validitas dan Reliabilitas}

Uji Validitas

Uji validitas digunakan untuk menguji apakah pertanyaan pada suatu kuesioner mampu untuk mengungkapkan sesuatu yang akan diukur oleh kuesioner tersebut. Dalam penelitian ini digunakan uji validitas item dengan menggunakan kriteria internal yaitu membandingkan kesesuaian tiap komponen pertanyaan dengan total skor keseluruhan tes. Caranya yaitu dengan mengkorelasikan antara skor pernyataan tertentu dengan skor total skala sikap. Dasar pengambilan keputusan menurut Masri Singarimbun dan Sofian Effendi (1987) dengan tingkat signifikansi $5 \%$.

\section{Uji Reliabilitas}

Uji reliabilitas merupakan salah satu cara yang dapat dilakukan untuk menguji sejauh mana pengukuran memberikan hasil yang relatif stabil bila dilakukan pengukuran kembali. Pengujian reliabilitas diperlukan untuk hal-hal yang menyangkut sosial psikologis seperti sikap, perilaku dan kecenderungan. Dalam penelitian ini menggunakan SPSS, dimana suatu konstruk atau variabel dikatakan reliabel jika memberikan nilai Cronbach Alpha $(\alpha)>0,6$ (Nunnally, 1967).

\section{Uji Asumsi klasik}

\section{Uji Multikolinearitas}

Uji multikolinieritas bertujuan untuk menguji apakah dalam model regresi ditemukan adanya korelasi antar variabel bebas. Model regresi yang baik seharusnya tidak terjadi korelasi di antara variabel bebas. Jika variabel bebas saling berkorelasi, maka variabel-variabel ini tidak ortogonal. Variabel ortogonal adalah variabel bebas yang nilai korelasi antar sesama variabel bebas sama dengan nol. Untuk mendeteksinya yaitu dengan cara menganalisis nilai tolerance dan variance inflation factor (VIF). Apabila nilai tolerance mendekati angka satu dan VIF disekitar angka satu maka regresi bebas dari multikoleaniritas (Santoso,2000)

\section{Uji Heteroskedastisitas}

Uji heteroskedastisitas bertujuan menguji apakah dalam model regresi terjadi ketidaksamaan variance dari residual satu pengamatan ke pengamatan yang lain. Jika variance dari residual satu pengamatan ke pengamatan yang lain tetap, maka disebut homoskedastisitas dan jika berbeda heteroskedastisitas. Model regresi yang baik adalah yang homoskedastisitas atau tidak terjadi heteroskedastisitas.

Cara mendeteksinya adalah dengan cara melihat grafik plot antar nilai prediksi variabel terikat (ZPRED) dengan residualnya (SRESID). Deteksi ada tidaknya heteroskedastisitas dapat dilakukan dengan melihat ada tidaknya pola 
tertentu pada grafik scaterplot antar SRESID dan ZPRED dimana sumbu Y adalah $\mathrm{Y}$ yang telah diprediksi, dan sumbu $\mathrm{X}$ adalah residual (Y.Pred $-\mathrm{Y}$. Sesungguhnya) yang telah distudentized analisisnya:

1. Jika ada pola tertentu seperti titik-titik yang ada membentuk pola tertentu yang teratur (bergelombang, melebar, kemudian menyempit), maka mengindikasikan telah terjadi heteroskedastisitas.

2. Jika tidak ada pola yang jelas, serta titik-titik yang menyebar di atas dan di bawah angka nol pada sumbu Y, maka tidak terjadi heteroskedastisitas.

\section{Uji Normalitas}

Uji normalitas bertujuan untuk menguji apakah dalam model regresi variabel terikat dan variabel bebas keduanya mempunyai distribusi normal atau tidak. Model regresi yang baik adalah memiliki distribusi data normal atau mendekati normal. Caranya adalah dengan melihat normal probability plot yang membandingkan distribusi kumulatif dari distribusi normal. Distribusi normal akan membentuk satu garis lurus diagonal, dan ploting data akan dibandingkan dengan garis diagonal. Jika distribusi data adalah normal, maka garis yang menggambarkan data sesungguhnya akan mengikuti garis diagonalnya.

\section{Analisis Regresi Berganda}

Analisis regresi linier berganda digunakan untuk menganalisa pengaruh beberapa variabel bebas atau independen variabel $(\mathrm{X})$ terhadap satu variabel tidak bebas atau dependen variabel (Y) secara bersama-sama.

Persamaan Regresi Linier Berganda adalah:

$\mathrm{Yi}=\mathrm{a}+\mathrm{p}_{1} \mathrm{X}_{1}+\mathrm{p}_{2} \mathrm{X}_{2}+\mathrm{p}_{3} \mathrm{X}_{3}+\mathrm{e}$ Dimana,

Yi $\quad=$ variabel dependen,

$\mathrm{Xi}, \mathrm{X}_{2}, \mathrm{X}_{3}=$ variabel independen

a $\quad=$ konstanta,

$\mathrm{p}_{1}, \mathrm{p}_{2}, \mathrm{p}_{3}=$ koefisien masing-masing faktor

Dalam hubungan dengan penelitian ini, variabel independen adalah Kebijakan pupuk bersubsidi (X1), Regulasi Pupuk bersubsidi $\left(\mathrm{X}_{2}\right)$ dan Kinerja Pemasaran pupuk bersubsidi $\left(\mathrm{X}_{3}\right)$, sedangkan variabel dependen adalah Pendapatan petani padi (Y), sehingga persamaan regresi berganda estimasinya: $\mathrm{Yi}=\mathrm{a}+\mathrm{P}_{1} \mathrm{X}_{1}+\mathrm{p}_{2} \mathrm{X}_{2}+\mathrm{p}_{3} \mathrm{X}_{3}+\mathrm{e}$

Dimana, $\mathrm{Yi}=$ pendapatan petani padi

$\mathrm{A}=$ Konstanta dari persamaan regresi

$\mathrm{P}_{1} \quad=$ koefisien regresi dari variable $\mathrm{Xi}$, kebijakan pupuk bersubsidi

$\mathrm{p}_{2} \quad=$ koefisien regresi dari variable $\mathrm{X}_{2}$, Regulasi Pupuk bersubsidi

$\mathrm{p}_{3}=$ koefisien regresi dari variable $\mathrm{X}_{3}$, kinerja pemasaran pupuk bersubsidi

$\mathrm{X}_{1} \quad=$ Kebijakan pupuk bersubsidi

$\mathrm{X}_{2}=$ Regulasi pupuk bersubsidi

$\mathrm{X}_{3}=$ Kinerja pemasaran pupuk bersubsidi

Uji Hipotesis

$e \quad=$ Variabel pengganggu

\section{Pengujian Parsial (Uji t)}

Pengujian ini bertujuan untuk menguji pengaruh variabel bebas terhadap variabel terikat secara terpisah. Untuk regresi I : 
1. Membuat hipotesis untuk kasus pengujian t-test di atas, yaitu :

$\mathrm{Ho}: \mathrm{pi}=0$, artinya tidak ada pengaruh $\mathrm{Xi}, \mathrm{X}_{2}, \mathrm{X}_{3}$ terhadap $\mathrm{Y}_{\mathrm{i}}$

$\mathrm{HA}:$ pi $* 0$, artinya ada pengaruh $X_{u} \mathrm{X}_{2}, \mathrm{X}_{3}$ terhadap Yi.

2. Menentukan t hitung.

Dengan tingkat kepercayaan sebesar $95 \%$ atau taraf signifikansi sebesar 5

$\%$ maka jika t hitung memiliki signifikansi lebih kecil dari 0,05 mempunyai pengaruh yang signifikan terhadap variabel terikat.

\section{Uji Simultan (Uji f)}

Digunakan untuk mengetahui tingkat kelayakan model dari variabelvariabel yang digunakan mampu menjelaskan fenomena yang dianalisis. Apakah variabel bebas yang digunakan mampu menjelaskan variabel terikat.

Untuk regresi I : 1 . Membuat hipotesis untuk kasus uji F, yaitu :

- Ho : pi $=0$, artinya tidak ada pengaruh $\mathrm{X}_{1}, \mathrm{X}_{2}, \mathrm{X}_{3}$ terhadap $\mathrm{Yi}$

- HA : pi * 0 , artinya ada pengaruh $\mathrm{X}_{1} \mathrm{X}_{2}, \mathrm{X}_{3}$ terhadap Yi.

Menentukan $\mathrm{F}$ hitung.

Dengan tingkat kepercayaan sebesar $95 \%$ atau taraf signifikansi sebesar $5 \%$ maka:

- Jika f hitung memiliki signikansi kurang dari 5\%, maka Ho ditolak, berarti masing-masing variabel bebas secara bersama-sama mampu menjelaskan variabel terikat.

- Jika f hitung memiliki signifikansi lebih dari 5\%, maka Ho diterima, berarti masing-masing variabel bebas secara bersama-sama tidak mampu menjelaskan variabel terikat.

\section{Koefisien Determinasi $\left(\boldsymbol{R}^{2}\right)$}

Digunakan untuk mengukur kebenaran penggunaan model analisis regresi. Jika nilai $R^{2}$ mendekati angka 1 maka variabel bebas makin mendekati hubungan dengan variabel terikat atau dapat dikatakan bahwa penggunaan model tersebut dapat dibenarkan. Dari koefisien determinasi ini dapat diperoleh suatu nilai untuk mengukur besarnya sumbangan dari variabel $X$ terhadap variasi naik turunnya variabel Y, yang biasanya dapat dinyatakan pula dalam prosentase.

\section{HASIL PENELITIAN DAN PEMBAHASAN \\ Deskripsi Hasil penelitian}

Penelitian ini menggunakan responden petani pedagang dan penyalur pupuk di Kota Padang yaitu sebanyak 85 orang. Sebanyak 85 kuesioner disebarkan, telah diisi oleh seluruh responden secara lengkap, dan dikembalikan secara utuh. Untuk memberikan gambaran secara detil tentang data umum dari hasil jawaban responden penelitian penelitian secara rinci permasing-masing item pertanyaan yang menyangkut data umum kuesioner tersebut dilihat sebagai berikut :

Hasil analisa reliabilitas terhadap semua variabel yaitu Kebijakan Pupuk Bersubsidi(X1), Saluran Distribusi Pupuk Bersubsidi (X2) , Kinerja Pemasaran Pupuk Bersubsidi ( X.3) dan Pendapatan Petani Padi (Y) diringkas dan disajikan pada tabel 4.6. Tabel tersebut menunjukkan bahwa nilai Cronbach's alpha untuk variabel Kebijakan Pupuk Bersubsidi(X1) adalah sebesar 0,857 dengan 15 item pertanyaan, Saluran Distribusi Pupuk Bersubsidi (X2) sebesar 0,813 dengan 14 item pertanyaan, Kinerja Pemasaran Pupuk Bersubsidi ( X.3) sebesar 0,778 
dengan 8 item pertanyaan, dan Pendapatan Petani Padi (Y) sebesar 0,896 dengan 14 item pertanyaan,valid.

Berdasarkan hasil analisa realibitas yang disajikan pada tabel diatas, maka dapat diinterpretasikan bahwa semua variabel dalam penelitian ini yaitu Kebijakan Pupuk Bersubsidi (X1), Saluran Distribusi Pupuk Bersubsidi (X2), Saluran Distribusi Pupuk Bersubsidi dan Kinerja Pemasaran Pupuk Bersubsidi (X3) adalah reliabel atau andal (Sekaran, 2003). Dengan kata lain, semua butir pertanyaan yang digunakan dalam mengukur masing-masing variabel adalah stabil dan konsisten. Output lengkap SPPS dapat dilihat pada Lampiran .

\section{Analisa Korelasi}

Analisis korelasi merupakan suatu teknik statistik yang digunakan untuk mengukur keeratan hubungan antara dua variabel (Kuncoro, 2003).

Dalam penelitian ini, hubungan antar variabel penelitian yaitu Kebijakan Pupuk Bersubsidi(X1) , Saluran Distribusi Pupuk Bersubsidi (X2) , Kinerja Pemasaran Pupuk Bersubsidi ( X.3) dan Pendapatan Petani Padi (Y) dianalisa melalui korelasi bivariat (bivariate correlation) dengan menggunakan Person's correlation.

Secara spesifik, besarnya nilai korelasi antara Kebijakan Pupuk Bersubsidi(X1) dan Pendapatan Petani Padi (Y) adalah 0,263 atau sebesar 26,3\% dengan tingkat signifikansi 0,015. Sedangkan besarnya nilai korelasi antara Saluran Distribusi Pupuk Bersubsidi (X2) dan Pendapatan Petani Padi (Y) adalah 0,432 atau 43,2 \% dengan tingkat signifikansi 0,000. Kinerja Pemasaran Pupuk Bersubsidi (X3) dan Pendapatan Petani Padi (Y) adalah 0,354 atau 35,4 \% dengan tingkat signifikansi 0,01 Berdasarkan besarnya nilai korelasi tersebut, secara statistik dapat diinterpretasikan bahwa hubungan atau korelasi Kebijakan Pupuk Bersubsidi(X1) dengan Pendapatan Petani Padi (Y) lebih kuat atau erat jika dibandingkan dengan hubungan Saluran Distribusi Pupuk Bersubsidi (X2) dan Pendapatan Petani Padi,serta hubungan antara Kinerja Pemasaran Pupuk Bersubsidi (X3) dan Pendapatan Petani Padi (Y).

\section{Pengujian Hipotesis}

\section{Analisa Regresi Berganda}

Analisa regresi berganda merupakan suatu teknik statistik yang digunakan untuk mengetahui seberapa besar pengaruh beberapa variabel bebas terhadap variabel terikat (Kuncoro, 2003). Tujuan menggunakan analisa regresi berganda dalam penelitian ini adalah untuk mengetahui seberapa besar pengaruh variabel Kebijakan Pupuk Bersubsidi(X1), Saluran Distribusi Pupuk Bersubsidi (X2), Kinerja Pemasaran Pupuk Bersubsidi ( X3) terhadap Pendapatan Petani Padi (Y).

Memperlihatkan besarnya nilai $\mathrm{R}^{2}$ ( $R$ square) atau koefisien determinan adalah 0,278. Besarnya nilai tersebut dapat diinterpretasikan bahwa variansi Pendapatan Petani Padi (Y) pegawai Dinas Pemadam Kebakaran Kota Padang dijelaskan oleh variabel Kebijakan Pupuk Bersubsidi (X1), Saluran Distribusi Pupuk Bersubsidi (X2), dan Pendapatan Petani Padi Pemasaran Pupuk Bersubsidisecara simultan sebesar 27,8 \%. Dengan kata lain, pengaruh variabel Kebijakan Pupuk Bersubsidi(X1), Saluran Distribusi Pupuk Bersubsidi (X2), dan Kinerja Pemasaran Pupuk Bersubsidi (X3) terhadap Pendapatan Petani Padi (Y) 
adalah sebesar $27,8 \%$. Sedangkankan sisanya sekitar $72,2 \%$ dipengaruhi oleh variabel lainnya yang tidak termasuk dalam model penelitian ini.

pengujian hipotesis penelitian yaitu $\mathrm{H} 1$ dan $\mathrm{H} 2$ dan $\mathrm{H} 3$ tentang pengaruh variabel Kebijakan Pupuk Bersubsidi(X1), Saluran Distribusi Pupuk Bersubsidi (X2),dan Kinerja Pemasaran Pupuk Bersubsidi (X3) terhadap Pendapatan Petani Padi (Y), maka dapat dilihat sebagai berikut:

a) Nilai koefisien regresi (beta) variabel Kebijakan Pupuk Bersubsidi (X1) adalah sebesar 0,166 dengan tingkat signifikansi sebesar 0,049. Besarnya nilai signifikansi tersebut berada di bawah 0,05. Dengan demikian, dapat disimpulkan bahwa variabel Kebijakan Pupuk Bersubsidi (X1) berpengaruh signifikan terhadap Pendapatan Petani Padi (Y). Oleh karena itu hipotesis pertama Diterima. Artinya semakin baik Kebijakan Pupuk Bersubsidi, maka semakin baik pula Pendapatan Petani Padi Kota Padang.

b) Nilai koefisien regresi (beta) variabel Saluran Distribusi Pupuk Bersubsidi (X2) adalah sebesar 0,351 dengan tingkat signifikansi sebesar 0,001. Besarnya nilai signifikansi tersebut berada di bawah 0,05. Dengan demikian, dapat disimpulkan bahwa variabel Saluran Distribusi Pupuk Bersubsidi (X2) berpengaruh signifikan terhadap Pendapatan Petani Padi (Y). Artinya : Semakin baik Saluran Distribusi Pupuk Bersubsidi (X2), maka akan semakin baik pula Pendapatan Petani Padi (Y). Oleh karena itu hipotesis kedua (H2) penelitian ini diterima.

c) Nilai koefisien regresi (beta) variabel Kinerja Pemasaran Pupuk Bersubsidi $\left(\mathrm{X}_{3}\right)$ adalah sebesar 0,179 dengan tingkat signifikansi sebesar 0,041 . Besarnya nilai signifikansi tersebut berada dibawah 0,05. Dengan demikian, dapat disimpulkan bahwa variabel Kinerja Pemasaran Pupuk Bersubsidi $\left(\mathrm{X}_{3}\right)$ berpengaruh signifikan terhadap Pendapatan Petani Padi (Y). Oleh karena itu hipotesis kedua (H3) penelitian ini" Diterima

\section{Pembahasan}

\section{Hubungan Kebijakan Pupuk Bersubsidi dengan Pendapatan Petani Padi}

Tujuan pertama dari penelitian ini adalah mengetahui pengaruh Kebijakan

Pupuk Bersubsiditerhadap Pendapatan Petani Padi Kota Padang. Hasil analisa statistik dengan menggunakan regresi berganda menunjukkan bahwa hipotesis tersebut Diterima.

Hal ini dapat dibuktikan dengan ditemukan hasil koefisien regresi variabel Kebijakan Pupuk Bersubsidi sebesar 0,166 dengan tingkat signifkansi 0,049 ( $\beta=$ 0,$049 ; \mathrm{p}<0,05$ ). Hasil penelitian ini memberikan indikasi bahwa Kebijakan Pupuk Bersubsidi berpengaruh signifikan terhadap Pendapatan Petani Padi Kota Padang.

\section{Hubungan Saluran Distribusi Pupuk Bersubsidi dengan Pendapatan Petani Padi}

Hal ini dapat dibuktikan dengan ditemukan hasil koefisien regresi variabel Kebijakan Pupuk Bersubsidi sebesar 0,351 dengan tingkat signifkansi 0,001 ( $\beta$ $=0,001 ; \mathrm{p}<0,05)$. Hasil penelitian ini memberikan indikasi bahwa Saluran Distribusi Pupuk Bersubsidi berpengaruh signifikan terhadap Pendapatan Petani Padi pada Kota Padang 


\section{Hubungan Kinerja Pemasaran Pupuk Bersubsidi dengan Pendapatan Petani Padi}

Hal ini dapat dibuktikan dengan ditemukan hasil koefisien regresi variabel Kebijakan Pupuk Bersubsidi sebesar 0,179 dengan tingkat signifkansi 0,041 ( $\beta$ $=0,041 ; \mathrm{p}<0,05)$. Hasil penelitian ini memberikan indikasi bahwa Kinerja

Pemasaran Pupuk Bersubsidi berpengaruh signifikan terhadap Pendapatan Petani Padi Kota Padang

\section{Impilikasi}

Hasil penelitian ini memberikan implikasi bahwa semakin baik implementasi Kebijakan Pupuk Bersubsidi, Saluran Distribusi Pupuk Bersubsidi dan Kinerja Pemasaran Pupuk akan mampu untuk meningkatkan kepuasan masing-masing petugas dalam bekerja sehingga pada akhirnya nanti akan mampu untuk meningkatkan Pendapatan Petani Padi .

Dari hasil penelitian ini, Pendapatan Petani Padi Kota Padang tersebut akan dapat ditingkatkan dengan memperhatikan faktor - faktor yang bersangkutan dengan sistim nilai yang berlaku. Dengan demikian terdapat hubungan yang posistif antara Kebijakan Pupuk Bersubsidi, Saluran Distribusi Pupuk Bersubsidi dan Kinerja Pemasaran Pupuk dengan Pendapatan Petani Padi.

Menurut Boediono (2002) untuk menghitung pendapatan bersih usaha atau keuntungan usaha terlebih dahulu harus diketahui tingkat penerimaan total dan pengeluaran total pada periode tertentu.

Sebagai aplikasi dari teori yang dikemukakan diatas, maka hasil penelitian ini akan memberikan implikasi dari ketiga variabel bebas Kebijakan Pupuk Bersubsidi, Saluran Distribusi Pupuk Bersubsidi ,dan Pendapatan Petani Padi Pemasaran Pupuk Bersubsidi terhadap peningkatan Pendapatan Petani Padi.

\section{Kesimpulan}

Berdasarkan hasil penelitian dan pembahasan yang telah disampaikan pada bab sebelumnya, maka berikut ini dapat dikemukakan beberapa kesimpulan dari penelitian ini sebagai berikut:

1. Kebijakan Pupuk Bersubsidi (X1) diukur dengan menggunakan 15 item pertanyaan dan semua pertanyaan adalah valid. Sedangkan variabel Saluran Distribusi Pupuk Bersubsidi (X2) yang diukur dengan menggunakan 16 item pertanyaan dimana 2 butir pertanyaan yang tidak valid, variabel Kinerja Pemasaran Pupuk Bersubsidi (X3) dengan menggunakan 10 Pertanyaan, dimana 2 pertanyaan dinyatakan tidak Valid. Selanjutnya variabel Pendapatan Petani Padi (Y) yang diukur dengan menggunakan 20 item pertanyaan ternyata 6 butir pertanyaan dinyatakan tidak valid.

2. Semua variabel penelitian memiliki nilai Cronbach's alpha diatas 0,70 dan dengan demikian dinyatakan reliabel atau andal. Nilai Cronbach's alpha variabel Kebijakan Pupuk Bersubsidi(X1) adalah sebesar 0,857, variabel Saluran Distribusi Pupuk Bersubsidi (X2) sebesar 0,813, variabel Kinerja Pemasaran Pupuk Bersubsidi (X3) sebesar 0,736, serta variabel Pendapatan Petani Padi (Y) adalah sebesar 0,844.

3. Ketiga variabel bebas dalam penelitian ini yaitu Kebijakan Pupuk Bersubsidi (X1) Saluran Distribusi Pupuk Bersubsidi (X2), dan Kinerja Pemasaran Pupuk 
Bersubsidi (X3) berkorelasi signifikan dengan variabel Pendapatan Petani Padi (Y) sebagai variabel terikat.

4. Pada pengujian hipotesis penelitian ditemukan hasil bahwa nilai signifikasi Variabel Kebijakan Pupuk Bersubsidi (X1) adalah dengan nilai ( sign $\beta=$ 0,049; $\mathrm{p}<0,05)$, variabel Saluran Distribusi Pupuk Bersubsidi (X2) dengan nilai (sign $\beta=0,001 \mathrm{p}<0,05)$, dan variabel Kinerja Pemasaran Pupuk Bersubsidi $(Y)$ dengan nilai $(\operatorname{sign} \beta=0,041 \mathrm{p}<0,05)$.

5. Dengan ditemukannya nilai sign $\beta$ tersebut diatas maka dinyatakan bahwa ketiga variabel bebas Kebijakan Pupuk Bersubsidi(X1), Saluran Distribusi Pupuk Bersubsidi (X2) dan Kinerja Pemasaran Pupuk Bersubsidi (Y) adalah berpengaruh signifikan terhadap Pendapatan Petani Padi (Y) Kota Padang.

6. Besarnya pengaruh ketiga variabel bebas yaitu Kebijakan Pupuk Bersubsidi (X1) dan Saluran Distribusi Pupuk Bersubsidi (X2), Kinerja Pemasaran Pupuk Bersubsidi(X3) terhadap Pendapatan Petani Padi (Y ) Kota Padang adalah $27,8 \%\left(\mathrm{R}^{2}=0,278\right)$.

\section{Saran}

Disarankan kepada pengambil Kebijakan Kota Padang agar memperhatikan beberapa aspek, antara lain :

1. Pada Variabel Kebijakan Pupuk Bersubsidi sehubungan dengan item pertanyaan nomor 4 dengan item memiliki nilai rata-rata terendah diantara item pertanyaan lainnya, maka disarankan agar Kebijakan Pupuk Bersubsidi yang dipakai adalah dengan cara menimbulkan suasana saling percaya dan menghilangkan ketidakberesan dalam organisasi tersebut.

2. Pada Variabel Saluran Distribusi Pupuk Bersubsidi sehubungan dengan item pertanyaan nomor 10 dengan item memiliki nilai rata-rata terendah diantara item pertanyaan lainnya, adanya peningkatan peran pemerintah dan PPL, pembinaan, dan pendampingan terhadap petani serta kerjasama yang terorganisir dengan baik antara pemerintah, PPL, dan petani sehingga dapat meningkatkan pengetahuan dan keterampilan petani mulai dari kegiatan persiapan tanam, penanaman, pemeliharaan, panen, dan pascapanen sehingga pada akhirnya produksi dan pendapatan petani padi dapat ditingkatkan.

3. Pada Variabel Kinerja Pemasaran Pupuk Bersubsidi sehubungan dengan item pertanyaan nomor 2 dengan item memiliki nilai rata-rata terendah diantara item pertanyaan lainnya, maka disarankan agar pekerjaan yang dilakukan sehari-hari mampu untuk memuaskan masyarakat dalam bekerja.

4. Pada Variabel Pendapatan Petani Padi sehubungan dengan item pertanyaan nomor 17 dengan item memiliki nilai rata-rata terendah diantara item pertanyaan lainnya, maka disarankan agar pekerjaan yang dilakukan sehariharinya diberikan waktu istirahat yang tidak melebihi dari ketentuan jam kerja yang telah ditetapkan.

\section{DAFTAR PUSTAKA}

Ass'ad Mohd,( 1998)Penilaian Pendapatan Petani Padi Organisasi,Bumi Aksara,Jakarta

Bas Bernards JH 1990, terjemahan H.Sulisstyio, Organisasi dan Manjemen, Erlangga Jakarta 
Bycio(1995), Management of Organization As Behaviou, Utilizing Human Resource, Fifth Edition, New York. Prantice Hall. Engelwood Cliffs Jersey.

Benardin H, Jhon and Russel, Joyce C.A,2003, Human Resiources Management : An Experimental Appriach, Mc. Graw Hill inc. Singapura

Blurn. 1982.terjemahan," Perilaku dalam Organisasi. Jakarta : Erlangga

Dessler, Garry, 1998, Manajemen Sumber Daya Manusi, Human Resource Management 7e. Penterjemah : Benyamin Molan PT Prenhallindo, Jakarta

Daft (2002) Management of Organization Behaviou, Utilizing Human Resource, Fifth Edition, New York. Prantice Hall. Engelwood Cliffs Jersey

Dinner \& Giffin ., Management Public Policy Analysis: An Introduction, Prentice Hall Inc, Englewood Clivffs, 1981.

Danim ,2004) "Motivation to Organization and Occupation : Extention and test of Tree-Component Conceptullization " Journal of Applied Psychology, Vol 78 N0. 4

Gozali, (2007), Aplikasi Analisis .multivariate dengan program SPSS, Edisi I Semarang

Gomez dan R M.Diensech ( 1995) “ Organizational Citizen Behaviour Construct Redefinitiont Measurement and Validition."Academy Of Manajemen Journal Vol.37 .4 765-802

Gibson, Ivancevich, Donnelly(2001), Organizations, Richard. D. Irwin. Inc.

Gilmert (2003) “ Measurement Of Human Sevice Statisfaction Development Of The Job" Survey.American Journal Of Community

Hasibuan . S. Melayu, 2005. Managemen Sumber Daya Manusi, Bumi Aksara. Jakarta.

Hariman.Hilgert(1962).Human Resource Planning: Challenges for Industrial/Organization Psychologists. New York, West Publishing Company .

Hatry, Strategi Teintegrasi Dalam Perencanaan SDM , dalam Dwiyanto Agus, Pendapatan Petani Padi Organisasi Publik, kebijakan dan Penerapannya, 1995 (Makalah).

Howell (1999). Organisasi dan Manajemen Prilaku, Striktur, Proses. Alaih Bahasa : Djoerban Wahid, SH. Jakarta : Erlangga

Handoko T. Tani, (1997), Manajemen, BPFE Edisi Kedua, Yogyakarta

Hezbberg, Robert L.(1999), The Making of Human Reseources Development, Prenctice-Hall, Inc., Englewoods Cliffs, New Jersey, USA, 1985.

Judge \& Locke ( 1993)., Principles of Human Resource Development, AddisonWesley Publishing Company Inc, Orlando, 1989.

Kartono, Kartini, Pemimpin dan kepemimpinan, Grafindo, Jakarta, 1998

Keban, Yeremias, T, 1995, Indikator Pendapatan Petani Padi Pemerintah Daerah : Pendekatan Manajement dan Kebijakan, Seminar Sehari Pendapatan Petani Padi Organisasi Sektor Publik, Kebijakan dan Penerapan, 20 Mei 1995, Yogyakarta, MAP-UGM.

Kemalawarta (2000)., Kepemimpinan (Leadership), PT. Karya Nusantara, Bandung

Kuncoro, M. (2003). Metode Riset untuk Bisnis \& Ekonomi, Bagaimana Meneliti 
Lawer (1993(, Structure In Five; Designing Effective Organizations, PrenticeHall, 1983Menulis Tesis. Erlangga, Jakarta

Locke ( 2002) The Six Key To Company Succes, Elex Media Komputindo, Jakarta,1995. (terjemahan

Manulang (1982). Manajemen Sumber Daya Manusia Perusahaan. Bandung : PT. Remaja Rosakarya

Martoyo(2000). Pengaruh Faktor-Fakor Kompetensi Terhadap Peningkatan

Pendapatan Petani Padi Pemasaran Pupuk BersubsidiKaryawan, ,

Proceeding Seminar Nasional, Akademi Manajemen Indonesia,Hotel

Sahid, 19 Oktober 2002, Surabaya

Milton (1981),Effectivity of Organization As Behaviou, third Edition, New York.

Prantice Hall. Engelwood Cliffs Jersey.

Nawawi , Organisasi dan Administrasi Pemerintah, Makalah,2000.

Mithcel (1995),Organisasi dan Manajemen Prilaku, Striktur, Proses. Alaih Bahasa : Djoerban Wahid, SH. Jakarta : Erlangga

Noe,Hollen,Gerhart,Wrigh,Mondyt (1994). Organisasi dan Manajemen Prilaku, Striktur, Proses. Alaih Bahasa : Djoerban Wahid, SH. Jakarta : Erlangga

Pujaatmaka ( 1996)Organisasi dan Administrasi Pemerintah, Makalah,2000.

Podasakoff, 1997, Manajemen Sumber Daya Manusia Untuk Bisnis Yang

Kompetitif, ( Alih bahasa Heru Susanto,Gajah Mada Yogyakarta

Rivai,2003. Manajemen Sumber Daya Manusia. Bandung : Remaja Rosdakarya.

Robbins, Stephen. P.(1996). Prilaku Organisasi. Jakarta. PT Macanan Jaya Cemerlang.

Schalarry \& Jackson ,1999,Human Resource Management, Massahusetts, Allyn \& Bacon

Siagian P. Sondang, (1998), Manajemen Sumber Daya Manusia, Bumi Aksara Jakarta.

Sekaran, U. 2003, Reseach Method For Busness USA. Jhon Wiley \& Sons Inc

Strauss and Sayless ( 1990), Service Management for Competitive Advantage, Mc Graw Hill, London.

Stoner, James AF,R Edwar Freeman dan Daniel R. Gilbert Jr, 1996. Managemen Edisis Bahasa Indonesia. Jakarta : Prenhalindo.

Solso (1998). Kepemimpinan Dalam Manajemen Sumber Daya Manusia. Jakarta. Djamabatan

Terry, (1990), Prinsip - prinsip Manajemen, Bumi Aksara, Jakarta

Truckenbold ,Gerhart,Wrigh,Mondyt (2000). Organisasi dan Manajemen Prilaku, Striktur, Proses. Alaih Bahasa : Djoerban Wahid, SH. Jakarta : Erlangga

Welliam, Henry, ( 2003) Structure In Five; Designing Effective Organizations, Prentice-Hall,

Wursanto ( 2001), Manajemen Strategik: Pengantar Proses Berfikir Strategis, Binarupa Aksara, Jakarta,

Weither Dan Davis, 1997, Banishing Bureaucracy : The Five Strategies for Reinventing Government, New York, Addison-Wesley.

Yudistira, D. S., \& Susanti, F. (2019). Pengaruh Motivasi Kerja Dan Budaya Kerja Terhadap Kinerja Karyawan Dinas Pemberdayaan Masyarakat Dan 
Desa, Pengendalian Penduduk Dan Keluarga Berencana Kabupaten Pesisir Selatan. https://doi.org/10.31227/osf.io/jk54m

Ridho, M., \& Susanti, F. (2019). Pengaruh Stres Kerja Dan Motivasi Kerja Terhadap Kepuasan Kerja Pada Karyawan Bank Mandiri Syariah Cabang Padang. https://doi.org/10.31227/osf.io/pa2cg

Lubis, A. Y. O., \& Susanti, F. (2019). Pengaruh Gaya Kepemimpinan Dan Kompensasi Terhadap Prestasi Kerja Karyawan (Studi pada PT Japfa Comfeed Indonesia (JCI) Tbk Devisi Fam 1. https://doi.org/10.31227/osf.io/7tbrg

Aldi, Y., \& Susanti, F. (2019). Pengaruh Stress Kerja Dan Motivasi Kerja Terhadap Prestasi Kerja Karyawan Pada PT. Frisian Flag Indonesia Wilayah Padang. https://doi.org/10.31227/osf.io/et4rn

Widodo, B. H., \& Susanti, F. (2019). Pengaruh Human Relation (Hubungan Antar Manusia), Lingkungan kerja Terhadap Etos Kerja karyawan (Studi Kasus Pada PT. Pelindo Teluk Bayur Padang ). https://doi.org/10.31227/osf.io/dxm8a

Junaidi, R., \& Susanti, F. (2019). Pengaruh Gaya Kepemimpinan Dan Budaya Organisasi Terhadap Kinerja Pegawai Pada UPTD Baltekkomdik Dinas Pendidikan Provinsi Sumatera Barat. https://doi.org/10.31227/osf.io/bzq75

Selamat, S. Heryanto, H. (2019). Affecting Factors In Employee Performance Koto Baru Sub-District, Dharmasraya District. Archives of Business Research 7 (7), 142-154

Ermayenti, E. Heryanto, H. (2019). The Effect Of Competence And Discipline Of Work On Public Satisfaction In The Regional Office Of The Ministry Of Religion In West Sumatera Province With Quality Of Service As An Intervening Variable. Archives of Business Research 7 (7), 69-87

Kurniawan, H. Heryanto, H. (2019). Effect of Work Discipline and Work Environment on Employee Performance with Work Motivation as an Intervening Variable in Department of Tourism, Youth and Sport of Padang District. Archives of Business Research 7 (7), 88-101

Sari, N. Heryanto, H. (2019). The Effect Of Training And Utilization Of SIPKD On Competency And Its Impact On The Quality Of Financial Statements In Dharmasraya Regency SKPD. Archives of Business Research 7 (7), $112-121$

Fatra, A. Heryanto, A. (2019). The Effect Of Implementation Of Population Administration Policy And Employee Motivation On Quality Of Service And Its Impact On Community Satisfaction In Issuance Of Birth ACCESS (Case in: The Department of Population and Civil Registration of the Dharmasraya Regency). Archives of Business Research 7 (7), 155-165

Yusrisal, Y. Heryanto, H.( 2019). The Influence of Leadership and Competence on Work Motivation and its impact on Employee Performance at the Koto Besar Sub-District Office, Dharmasraya Regency. Archives of Business Research 7 (7), 122-131

Syukri, M. Heryanto, H. (2019). The Influence Of Leadership Style, And Organizational Commitment, On Employee Discipline And Also Its Impact On Employee Performance Of The Dharmasraya District 
Community And Village Empowerment Office. Archives of Business Research 7 (7), 102-111

Septria, D. Heryanto, H. (2019). Performance Capability Analysis and Regional Budget Evaluation in Implementing Regional Autonomy in Dharmasraya District. Archives of Business Research 7 (7), 180-187

Meldi, M. Heryanto, H. (2019). The Influence Of Quality Of Human Resources And Communication On The Performance Of Civil Servants In The Regional Secretariat Of Dharmasraya Regency With Organizational Commitment As Intervening Variables. Archives of Business Research 7 (7), 132-141

Wahyuni, N. Heryanto, H. (2019). The Effect of Environment and Motivation on Employee Performance with Organizational Culture as an intervening variable on Bank Perkreditan Rakyat Jorong Kampung Tangah Pariaman PT. Archives of Business Research 7 (5)

Khamri, A. Heryanto, H. (2019). The Influence of the Work Environment, Work Discipline on the Spirit of Work and Its Impact on Employee Performance at the Dharmasraya District Health Office. Archives of Business Research 7 (5)

Irvan, RM. Heryanto, H. (2019). The Effect of Competence and Workload on Motivation and Its Impact on the Performance of Civil Servants at the Regional Secretariat of the Regency of Dharmasraya. Archives of Business Research 7 (5)

Jamilus, J. Heryanto, H. (2019). The Effect of Competence, Communication \& Motivation on Employee Performance in People's Welfare Regional Secretariat of Padang City, Indonesia. Archives of Business Research 7 (5) Zukriah, A. Heryanto, H. (2019). The Effect Of Work Motivation And Discipline On Employee Performance In Human Resources Development Agency, West Sumatera With Education And Training As Variable Intervening. Archives of Business Research 7 (5)

Marunduri, P. Heryanto, H. (2019). Analysis of the Effect of Training and Motivation on Organizational Commitments and Its Impact on Employee Performance (Study on Insurance Marketing Agents on Prudential Agency Pru-Aini Gunung Sitoli PT). Archives of Business

Syamsudirman, S. Yurmain, H. Heryanto, H. (2019). Compensation and Work Culture on Organizational Performance with in mediation by Work Satisfaction in Fire Department Service of Sungai Penuh City. Archives of Business Research 7 (2)

Heryanto, H. (2019). The Effect of Work Motivation and Work Environment on Performance With Satisfaction as Intervening Variables Education Personnel Rektorate Andalas University. Archives of Business Research 7 (2)

Heryanto, H. Sumarni, S. (2019). The Effect of Certification, Competence, and Motivation on Teachers Performance of Country Civil Apparatus in Sawahlunto City. Archives of Business Research 7 (1)

Eliza, Y. (2015). Pengaruh moralitas individu dan pengendalian internal terhadap kecenderungan kecurangan akuntansi (Studi Empiris Pada SKPD di Kota 
Padang). Jurnal Akuntansi (Media Riset Akuntansi \& Keuangan) 4 (1), 86100

Eliza, Y. (2015). Pengaruh Investasi, Angkatan Kerja dan Pengeluaran Pemerintah terhadap Pertumbuhan Ekonomi di Sumatera Barat. PEKBIS (Jurnal Pendidikan Ekonomi Dan Bisnis) 7 (3), 198-208

Eliza, Y. Adriani, E. Maryanti, S. (2019). The Analysis Return on Investment Education of Married Woman in Indonesia. KnE Social Sciences, 667688-667-688

Maryanti, S. Eliza, Y. Wiyati, R. Thamrin, M. (2018). The Growth of the Population: Labor Potential Mapping in Pekanbaru Indonesia. IOP Conference Series: Earth and Environmental Science 175 (1), 012092

Eliza, Y. (2015). Analisis Kepuasan Masyarakat Atas Kualitas Pelayanan Kantor Kecamatan Siberut Selatan Kabupaten Kepulauan Mentawai. Jurnal Pendidikan Ekonomi dan Bisnis 7 (1), 65-75

Yuharmain, H. Suryana, Y. Novianty, R, Joeliaty. (2016). An Impact Study Of Rural Credit Bank Existence Towards Micro And Small Businesses In Padang City. International Journal Of Scientific \& Technology Research 5 (7), 145-150

Edasa, D. Putra, EE. (2015). Pengaruh Gaya Kepemimpinan, Lingkungan Kerja dan Motivasi Kerja Terhadap Kinerja Pegawai LPP-RRI Bukittinggi. Jurnal Riset Manajemen Bisnis dan Publik 3 (2)

Putra, EE. (2015). Keadilan Dalam Organisasi. Buletin Organisasi dan Aparatur

Putra, EE. (2015). Pentingnya ISO Bagi Lembaga Pendidikan Dan Latihan. Buletin Badan Diklat Prov. Sumatera Barat

Putra, EE. (2015). Urgensi Pengembangan Potensi Aparatur Sipil Negara (ASN). Buletin Badan Diklat Prov. Sumatera Barat

Putra, EE. (2014). The Effect of Human Capital, Structural and Customer Capital to Performance of Small Medium Enterprises at West Sumatera Province. Business Administration at Jose Rizal University

Putra, RY. Marlius, D. (2019). Pengaruh Pendidikan, Pengalaman Kerja dan Etos Kerja Terhadap Kinerja Pegawai Di KPN Batur. Academic Conference For Management 2.

Marlius, D. RD Putra. (2018). Strategi Pengembangan Sulam Bayang. Jurnal Benefita: Ekonomi Pembangunan Manajemen Bisnis Dan Akuntansi. Volume 3. No. 2. Hal. 204-218.

Marlius, D. (2017). Keputusan Pembelian Berdasarkan Faktor Psikologis Dan Bauran Pemasaran Pada PT. Intercom Mobilindo Padang. Jurnal Pundi. Volume 1. No. 1. Hal. 57-66. https://doi.org/10.31575/jp.v1i1.9

Marlius, D. (2016). Pengaruh Bauran Pemasaran Jasa Terhadap Minat Nasabah Dalam Menabung Pada Bank Nagari Cabang Muaralabuh. https://doi.org/10.31227/osf.io/vdqgx 